\title{
Novel inflammatory biomarkers in primary hyperparathyroidism
}

\author{
M H E Christensen ${ }^{1,2}$, I S Fenne ${ }^{1,2}$, Y Nordbø ${ }^{3}$, J E Varhaug ${ }^{3,4}$, K O Nygård 1,5,6, \\ E A Lien ${ }^{1,2}$ and $\mathbf{G}$ Mellgren ${ }^{1,2,5}$ \\ ${ }^{1}$ Department of Clinical Science, University of Bergen, Bergen, Norway, ${ }^{2}$ Hormone Laboratory and \\ ${ }^{3}$ Department of Surgery, Haukeland University Hospital, 5021 Bergen, Norway, ${ }^{4}$ Department of Surgical Science, \\ University of Bergen, Bergen, Norway, ${ }^{5} \mathrm{KG}$ Jebsen Center for Diabetes Research, Bergen, Norway and \\ ${ }^{6}$ Department of Heart Disease, Haukeland University Hospital, Bergen, Norway
}

Correspondence should be addressed to M H E Christensen Email monika.christensen@ k2.uib.no

\begin{abstract}
Objective: Primary hyperparathyroidism (PHPT) has been associated with low-grade inflammation and increased risk of cardiovascular disease (CVD). The aim of the study was to investigate systemic levels of pro-inflammatory proteins that previously have not been examined in patients with PHPT. The selection of the pro-inflammatory biomarkers included in this study, MMP9, S100A4, S100A8/A9 and the receptors SCD14 and RAGE, was based on a previous microarray screen of mRNAs in adipose tissue from PHPT patients.

Design: A prospective study was conducted on a total of 57 patients with PHPT and a control group of 20 healthy blood donors.

Methods: PHPT patients with normalisation of serum calcium levels after parathyroidectomy were followed for 6 months. Forty-two patients participated in the longitudinal study, in which blood samples were taken at inclusion, and 1, 3 and 6 months after surgery.

Results: We observed increased serum levels of MMP9 $(P=0.029), \mathrm{S} 100 \mathrm{~A} 4(P<0.001)$ and SCD14 $(P=0.002)$ in the 57 patients with PHPT compared to the control-group. During 6 months of follow up, S100A4 $(P=0.022)$ and SCD14 $(0.002)$ decreased significantly, while serum levels of MMP9 increased $(P=0.025)$.

Conclusions: The results demonstrate an increased inflammatory response in PHPT patients shown by elevated MMP9, S100A4 and sCD14 at inclusion. During the 6 months of follow-up, MMP9 increased further, possibly due to the tissue repair process after parathyroidectomy. S100A4 and SCD14 decreased after surgery demonstrating a partial reversal of the systemic inflammation.
\end{abstract}

\section{Introduction}

Patients with primary hyperparathyroidism (PHPT) have increased levels of parathyroid hormone (PTH) resulting in enhanced levels of serum calcium (Ca) (1). The most thoroughly investigated clinical feature in patients with PHPT is decreased bone mineral density (2). Additionally, several risk factors for cardiovascular disease (CVD) are observed in these patients, including increased inflammation, hypertension, left ventricular hypertrophy and metabolic changes $(3,4,5,6)$. Increased mortality in patients with PHPT is described, largely due to cardiovascular death $(7,8,9)$. Even though PHPT has changed to a more asymptomatic disease during the last decades, an increased disposition for CVD and mortality seems to persist, even at only slightly elevated levels of PTH (10). Serum PTH levels, rather than serum calcium, have been found to predict the longtime risk of both fatal and non-fatal CVD in untreated PHPT (11).

Most patients with PHPT have either a single adenoma producing excessive amounts of PTH or glandular hyperplasia. By removing the adenomas or hyperplastic glands,

Published by Bioscientifica Ltd. 
the rate of cure is about 90-95\% (12). Postoperatively there is a reversal of bone loss (13). Effects of surgery on inflammation have been conflicting. Some studies show that parathyroidectomy only has a modest effect on risk factors for CVD $(3,14,15)$, while others show at least partial reversal of the inflammation and the estimated risk of CVD $(8,16)$.

The pathogenesis of atherosclerosis is recognized as an inflammatory process. Atherosclerotic plaques are infiltrated by activated macrophages and lymphocytes, contributing to disease progression (17). Endothelial dysfunction represents a key step in the initiation and maintenance of atherosclerosis and may serve as a marker of future risk of cardiovascular events. Previously, we have reported that the expression of inflammatory genes was upregulated in subcutaneous neck adipose tissue from patients with PHPT. Several of these genes were related to infiltration and activation of macrophages (18).

In the present study, we have analysed the systemic levels of inflammatory factors that were previously identified in a microarray-based screen of mRNAs in adipose tissue (18), focusing on the pro-inflammatory proteins matrix metallopeptidase 9 (MMP9), the $\mathrm{S100}$ proteins S100A4 and S100A8/A9 as well as the soluble receptor sCD14. Of note, circulating levels of these proteins have been correlated to inflammation and increased risk of CVD $(19,20,21,22)$. Due to the close connection between the S100 proteins and the receptor for advanced glycation endoproducts (RAGE), we also analysed RAGE in order to have more information on the inflammatory process in patients with PHPT. Finally, we present data on the levels of these inflammatory biomarkers during 6 months of follow-up after parathyroidectomy, indicating at least a partial resolution of the systemic inflammation.

\section{Subjects and methods}

\section{Participants}

The study population, including 57 patients (48 females and nine males) undergoing surgery for PHPT and 20 healthy blood donors (15 females and five males) serving as control subjects, has been previously described (16). All subjects were recruited during the period from September 2007 to December 2010, and patients were operated at the Department of Endocrine Surgery, Haukeland University Hospital, Bergen, Norway. The diagnosis of PHPT was based on increased serum levels of both PTH (reference range: 1.3-6.8 pmol/l) and albumin corrected
Ca (2.20-2.55 mmol/l). Exclusion criteria were genetically confirmed multiple endocrine neoplasia type 1 , due to verified mutations in the MEN1-gene, as well as known systemic inflammatory disease, such as inflammatory bowel disease, rheumatoid diseases and chronic obstructive lung disease. At the clinical examination the day before surgery, morphometric data and medical history were recorded. Neither patients nor controls were instructed to be fasting prior to blood sampling.

Blood samples were drawn 1 day before as well as 1 , 3 and 6 months after surgery. At these prescheduled timepoints, patients received a written request for blood samples. Exclusion criteria for participating in the longitudinal study was persisting elevated corrected Ca levels during the 6 months of follow-up. In the follow-up study, 42 patients (four males and 38 females) participated.

The study was approved by the Western Norway Regional Committee for Medical Research Ethics. All enrolled subjects signed an informed written consent and the study was performed according to the principles expressed in the Declaration of Helsinki.

\section{Biochemical analysis and morphometric data}

Blood samples were centrifuged and frozen at $-80^{\circ} \mathrm{C}$ within $2 \mathrm{~h}$. Ca, ionised $\mathrm{Ca}$, albumin, phosphate, total alkaline phosphatase (ALP), alanine transaminase (ALAT) and $\mathrm{C}$-reactive protein (CRP) were analysed immediately at the Laboratory of Clinical Biochemisty, Haukeland University Hospital, Bergen, Norway, using the Modular P-system from Roche Diagnostics, Basel, Switzerland. Creatinine was analysed at Bevital A/S, Bergen, Norway, and was determined by including it and its deuterated internal standard (d3-creatinine) in an established liquid chromatography/tandem mass spectrometry (LC-MS/MS) assay using the ion pairs 114/44.2 and 117/47.2 respectively (23). The remaining analyses were performed at the Hormone Laboratory, Haukeland University Hospital, Bergen, Norway. PTH was analysed using a two-site chemiluminescent immunometric assay for intact PTH (Immulite 2000, Siemens Healthcare Diagnostics, Deerfield, IL, USA). Plasma concentrations of 25(OH)D were analysed by LC-MS/MS, with separate quantification of $25(\mathrm{OH}) \mathrm{D}_{3}$ and $25(\mathrm{OH}) \mathrm{D}_{2}(24) .1,25(\mathrm{OH})_{2} \mathrm{D}$ was analysed using the Immunodiagnostic system with a sensitivity of $100 \%$ for $1,25(\mathrm{OH})_{2} \mathrm{D}_{3}$ and $91 \%$ for $1,25(\mathrm{OH})_{2} \mathrm{D}_{2}$ (Boldon, UK). Detection limit was $8 \mathrm{pmol} / 1$ for $1,25(\mathrm{OH})_{2} \mathrm{D}$ and the inter-assay variations were 13.6 , 9.6 and $9.6 \%$ for concentrations of $20.5,60.8$ and $135.2 \mathrm{pmol} / \mathrm{l}$ respectively. 
Albumin corrected Ca was calculated by Payne's formula: corrected $\mathrm{Ca}=$ measured $\mathrm{s}-\mathrm{Ca}+0.025 \times$ (42-measured albumin) (25). In analyses that included both patients and controls, albumin corrected Ca was used as ionised $\mathrm{Ca}$ was not available for the controls. The isotope dilution mass spectrometry (IDMS) traceable formula developed by the Modification of Diet in Renal Disease (MDRD) Study Group was used for estimated glomerular filtration rate (eGFR) calculations: eGFR $=175 \times(\text { s-creatinine } / 88.4)^{-1.154} \times(\text { Age })^{-0.203} \times 0.742$ if female (26). BMI was calculated as weight divided by the square of body length $\left(\mathrm{kg} / \mathrm{m}^{2}\right)$. Patients with CRP-levels below the lowest detection limit for this analysis (CRP $<0.5 \mathrm{mg} / \mathrm{l}$ ) were included in the calculations with CRP levels of $0.4 \mathrm{mg} / \mathrm{l}$.

ELISA were used to detect the soluble biomarkers of inflammation, MMP9, the heterodimer S100A8/A9, S100A4, sCD14 and RAGE. The assays were performed according to the instructions of the manufacturer. MMP9, sCD14 and RAGE (R\&D Systems, Minneapolis, MN, USA) were measured in serum. For MMP9 intra-assay variation was $2.3 \%$ and the inter-assay variation $7.5 \%$. For RAGE, the intra-assay variation was $5.7 \%$ and the inter-assay variation $7.7 \%$, whereas for sCD14 the intra- and interassay variations were 5.5 and $6.3 \%$ respectively. S100A4 (Abnova Corporation, Tapei, Taiwan) and S100A8/A9 (Hycult Biotech, Plymouth Meeting, PA, USA) were measured in plasma. Patients with undetectable levels of S100A4 with the used kit were included in the calculations with S100A4 levels of $0.001 \mathrm{ng} / \mathrm{ml}$. For S100A4, the intraand inter-assay variations were 5.8 and $7.2 \%$ respectively, and for calprotectin S100A8/A9 the intra-assay variation was $6.0 \%$ and the intra-assay variation $8.4 \%$.

\section{Statistical analysis}

SPSS Statistics 19 for Mac (IBM Corporation, New York, NY, USA) was used for statistical analyses. Continuous variables are reported as median (25th to 75 th percentile) or mean (s.D.) and categorical variables as numbers (percentages). Where distributional assumptions were violated, measures were either square root transformed (MMP9, S100A8/A9 and RAGE) or ranked (S100A4 and CRP) to obtain normal distribution before used in statistical tests. Differences in baseline characteristics between the patients and controls were assessed using the Mann-Whitney $U$ test, independent samples $t$-test or $\chi^{2}$ test where appropriate. Age- and gender-adjusted analysis of covariance (ANCOVA) was used to assess differences in inflammatory markers between patients and controls. Linear trends over time between repeated endpoint measures were estimated with a random intercept mixed model. Correlations among continuous variables were assessed by Spearman rank correlation, adjusted for age, gender, BMI and creatinine. Paired samples t-test was used to assess differences between longitudinal samples at inclusion and after 1, 3 and 6 months. Wilcoxon signed-ranked test was used to assess differences in levels of CRP, PTH, corrected Ca, ALP and albumin between inclusion and 6 months follow-up. All tests were two-sided and $P<0.05$ was considered to be statistically significant.

\section{Results}

\section{Subject characteristics}

Baseline characteristics, which have been presented previously (16), are shown in Table 1 . Between the two groups there were no differences in gender distribution, age or BMI. As expected due to the diagnosis PHPT, patients had higher levels of PTH, albumin corrected Ca and ALP while phosphate levels were lower. Serum creatinine levels were lower in PHPT patients than in controls. Though, eGFR was similar between the two groups, indicating that kidney function did not differ between the PHPT patients and the controls. As expected, levels of $25(\mathrm{OH}) \mathrm{D}$ were lower in patients than in controls, whereas $1,25(\mathrm{OH})_{2} \mathrm{D}$ levels were higher in the patients. None of the patients or controls had known atherosclerotic diseases, except for one patient previously operated with a coronary artery bypass and one patient who had previously had a cerebrovascular accident. Two patients had known dietary regulated type 2 diabetes mellitus.

\section{Inflammatory markers and correlations at baseline}

The levels of serum MMP9, plasma S100A4 and serum sCD14 were higher in patients than controls at inclusion, whereas plasma S100A8/A9 and serum RAGE levels did not differ between the two groups (Table 2). Correlations between the biomarkers were assessed in patients at inclusion. Of note, MMP9 was positively correlated to CRP $(r=0.359, P=0.01)$ (Fig. 1A). Additionally, a positive correlation between S100A4 and S100A8/A9 $(r=0.306$, $P=0.029$ ) was observed (Fig. 1B). None of the inflammatory biomarkers measured were correlated to PTH, ionised $\mathrm{Ca}, 1,25(\mathrm{OH})_{2} \mathrm{D}$ or ALP. Of note, $25(\mathrm{OH}) \mathrm{D}$ was positively correlated to CD14 $(r=0.31, P=0.025)$. As expected, PTH and $1,25(\mathrm{OH})_{2} \mathrm{D}$ were positively correlated 
Table 1 Baseline characteristics of the patients with primary hyperparathyroidism and controls at inclusion. Values are given as mean (s.D.), median (25th to 75th percentile) or numbers (percentages). Reference values are shown in parentheses.

\begin{tabular}{|c|c|c|c|}
\hline & PHPT $(n=57)$ & Control $(n=20)$ & $P$ value \\
\hline Gender (\% females) & $48(84.2)$ & $15(75.0)$ & 0.36 \\
\hline Age (years) & $59.7(12.2)$ & $56.8(4.34)$ & 0.12 \\
\hline BMI $\left(\mathrm{kg} / \mathrm{m}^{2}\right)$ & $26.0(4.35)$ & $25.3(2.97)$ & 0.48 \\
\hline PTH (1.3-6.8 pmol/l) & $12.4(9.65-17.9)$ & $3.8(2.60-4.08)$ & $<0.001$ \\
\hline Corrected Ca $(0.2-2.55 \mathrm{mmol} / \mathrm{l})$ & $2.68(0.17)$ & $2.29(0.12)$ & $<0.001$ \\
\hline Phosphate $(0.85-1.50 \mathrm{mmol} / \mathrm{l})$ & $0.83(0.17)$ & $1.19(0.20)$ & $<0.001$ \\
\hline ALP (35-105 U/I) & $87.0(71.0-116.5)$ & $64.5(53.5-74.0)$ & $<0.001$ \\
\hline Albumin (34-48 g/l) & $45.7(2.44)$ & $47.2(4.33)$ & 0.17 \\
\hline Creatinine $(45-90 \mu \mathrm{mol} / \mathrm{l})$ & $65.4(59.1-76.3)$ & $75.8(65.5-90.7)$ & 0.042 \\
\hline eGFR (>60 ml/min per $\left.1.73 \mathrm{~m}^{2}\right)$ & $83.7(21.6)$ & $74.5(16.2)$ & 0.085 \\
\hline ALAT $(10-70 \mathrm{U} / \mathrm{l})$ & $26.0(18.0-31.8)$ & $21.5(16.3-31.0)$ & 0.32 \\
\hline 25(OH)D (50-114 nmol/l) & $67.6(21.7)$ & $79.4(20.8)$ & 0.041 \\
\hline $1,25(\mathrm{OH})_{2} \mathrm{D}(43-168 \mathrm{pmol} / \mathrm{l})$ & $158(53.8)$ & $113(28.3)$ & 0.001 \\
\hline
\end{tabular}

$P$ values are based on Student's $t$-test, Mann-Whitney $U$ test or $\chi^{2}$ test. Corrected Ca, albumin corrected calcium; ALP, alkaline phosphatase; eGFR, estimated glomerular filtration rate; ALAT, alanine transaminase; $25(\mathrm{OH}) \mathrm{D}$, 25-hydroxyvitamin $\mathrm{D} ; 1,25(\mathrm{OH})_{2} \mathrm{D}, 1$,25-dihydroxyvitamin $\mathrm{D}$.

$(r=0.383, P=0.007)$, as were PTH and ionised $\mathrm{Ca}$ $(r=0.593, P \leq 0.001), 1,25(\mathrm{OH}) 2 \mathrm{D}$ and ALP $(r=0.357$, $P=0.013)$, and ionised Ca and ALP $(r=0.375, P=0.009)$. The correlation analyses were adjusted for age, gender, BMI and creatinine.

\section{Changes in parathyroid status after surgery}

All patients underwent surgery for PHPT caused by either an adenoma or multi-glandular hyperplasia. If corrected calcium levels were within the normal range 6 months after surgery, patients were considered cured. Of the 57 patients included, 42 patients completed the follow-up study. Four patients were excluded from the longitudinal study due to the persisting elevated serum levels of corrected $\mathrm{Ca}$, while the remaining 11 patients were nonresponders who did not attend the follow-up visits. Median age of the 42 patients participating in the longitudinal study was 61.0 years and median BMI was $26.3 \mathrm{~kg} / \mathrm{m}^{2}$. Six months after surgery a significant decline in the levels of PTH (median $3.90 \mathrm{pmol} / \mathrm{l} \mathrm{vs}$ $12.6 \mathrm{pmol} / \mathrm{l}, P<0.001)$, corrected Ca (mean $2.32 \mathrm{mmol} / 1$ vs $2.69 \mathrm{mmol} / 1, P<0.001$ ), ALP (median $71.0 \mathrm{U} / 1$ vs $87.0 \mathrm{U} / 1, \quad P<0.001), \quad 1,25(\mathrm{OH})_{2} \mathrm{D} \quad$ (mean $108 \mathrm{pmol} / 1$ vs $158 \mathrm{pmol} / \mathrm{l}, P<0.001$ ) and albumin (mean $44.5 \mathrm{~g} / \mathrm{l} \mathrm{vs}$ $45.5 \mathrm{~g} / 1, P=0.004)$ were observed, whereas increased levels of phosphate (mean $1.03 \mathrm{mmol} / \mathrm{l}$ vs $0.84 \mathrm{mmol} / \mathrm{l}$, $P<0.001$ ) and 25(OH)D (mean $80.2 \mathrm{nmol} / 1$ vs $69.0 \mathrm{nmol} / \mathrm{l}$, $P=0.005)$ were found compared to the levels at inclusion. Levels of creatinine did not change significantly during the follow-up period.

\section{Changes in inflammatory markers during follow-up}

Changes in inflammatory markers after surgery were evaluated during the predetermined timepoints; 1,3 and 6 months after parathyroidectomy. As shown in Fig. 2, a gradual increase in MMP9 $(P$-trend $=0.025)$ across the four timepoints was observed. Both S100A4 $(P$-trend=0.022) and sCD14 $(P$-trend $=0.002)$ decreased during 6 months follow-up. When testing the different time-groups with paired sample $t$-test, the increase in MMP9 was significant from baseline first after 6 months $(P=0.017)$, while a significant decrease in sCD14 $(P=0.045)$ was observed already after 1 month. The levels of S100A4 were significantly changed across the 6 months $(P=0.022)$. RAGE was increased 1 month after parathyroidectomy $(P=0.001)$, but decreased thereafter. Due to the increase of

Table 2 Markers of inflammation in patients with primary hyperparathyroidism and control subjects at inclusion. Values are given as mean (s.D.) or median (25th to 75 th percentile).

\begin{tabular}{|c|c|c|c|}
\hline & PHPT $(n=57)$ & Controls $(n=20)$ & $P$ value \\
\hline MMP9 (ng/ml) & 380 (282-632) & $290(223-350)$ & 0.029 \\
\hline CRP (mg/l) & $1.00(0.40-3.00)$ & $1.00(0.40-3.00)$ & 0.374 \\
\hline S100A4 (ng/ml) & $7.88(2.56-26.6)$ & $0.39(0.39-1.82)$ & $<0.001$ \\
\hline $\begin{array}{l}\text { S100A8/A9 } \\
(\mathrm{pg} / \mathrm{ml})\end{array}$ & $109(82.3-216)$ & 95.9 (72.7-155) & 0.157 \\
\hline sCD14 (ng/ml) & $1564(330)$ & 1291 (189) & 0.002 \\
\hline RAGE (pg/ml) & $928(646-1218)$ & 979 (697-1267) & 0.889 \\
\hline
\end{tabular}

$P$ values are based on ANOVA (MMP9, RAGE, CD14 and S100A8/A9) or Mann-Whitney $U$ test (CRP and S100A4), adjusted for age and gender. MMP9, RAGE and S100A4 were square root transformed before used in the analysis. 

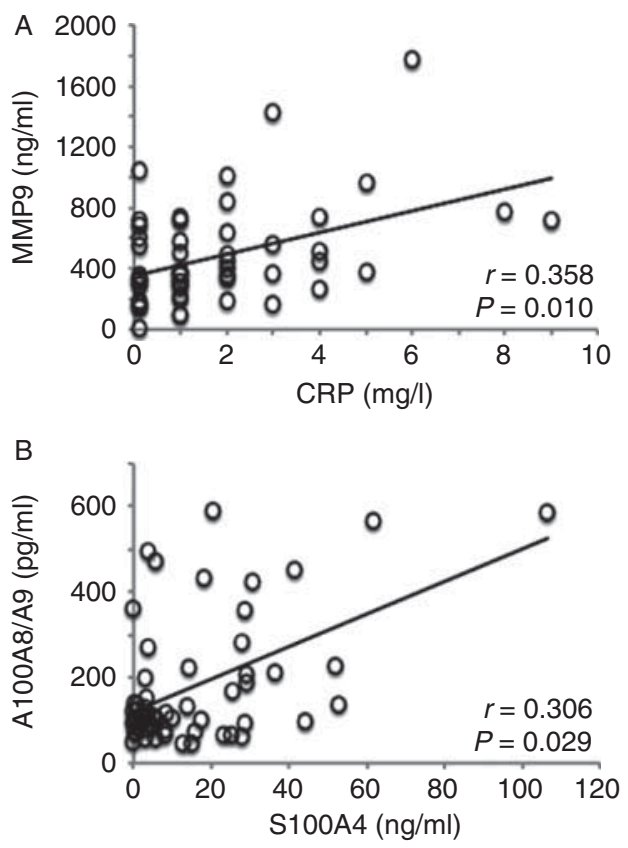

\section{Figure 1}

Inflammatory markers in primary hyperparathyroidism. The figure shows the association (Spearman's rank correlations, adjusted for age, gender, BMI and creatinine) between MMP9 and CRP in serum (A) and between S100A4 and S100A8/A9 in plasma (B). The samples were collected at baseline from 57 patients with PHPT.

RAGE at 1 month, RAGE had a decreasing trend during the 6 months $(P$-trend $=0.007)$. Though, serum concentrations of RAGE between inclusion and 6 months did not differ $(P=0.99)$. As previously described, CRP also increased significantly $(P=0.014)$ during the 6 months follow-up (16). Though, we only had measures for CRP at inclusion and at 6 months postoperatively.

\section{Discussion}

We observed increased serum levels of MMP9, S100A4 and sCD14 in patients with PHPT compared to a healthy control group. During 6 months of follow up, serum levels of MMP9 increased while sCD14 and S100A4 both decreased significantly. One month after surgery, the concentration of RAGE was increased, but concentrations returned to similar levels as at baseline during the remaining follow-up. Our findings suggest an increased inflammatory response in patients with PHPT and a partial reversal of the inflammation after surgery during 6 months follow-up.
The selection of the proteins analysed in this study was based on a previous gene expression study in adipose tissue from patients with PHPT (18). Both circulating blood levels of the proteins as well as adipose tissue mRNA levels (18) of MMP9, S100A4 and sCD14 were enhanced, showing a general low-grade inflammatory state in PHTP patients, which was present in different tissue compartments. Possibly, similar inflammatory changes might be detected in other tissues as well.

The myeloprotein MMP9 has been closely linked to increased risk of CVD (27). This endopeptidase is responsible for both physiological and pathophysiological tissue remodelling and is secreted by a wide number of cell types, including neutrophiles, macrophages and fibroblasts $(28,29)$. In both rheumatoid arthritis and osteoarthritis, MMP9 is elevated in the cartilage and synovial tissue, playing a significant role in the pathophysiology of these arthropathies (30). In atherosclerotic plaques, higher serum levels of MMP9 are associated with increased plaque instability (31). Additionally, patients with stable or unstable angina who had elevated systemic levels of MMP9 had higher Framingham cardiovascular risk score and increased risk of cardiovascular mortality (32). Thus, higher levels of MMP9 in patients with PHPT before surgery might indicate an increased risk of CVD in these patients. Surprisingly, levels of MMP9 increased during follow-up after surgery. It has previously been shown that transgenic overexpression of MMP9 in macrophages improved cardiac function and attenuated inflammatory response at day 5 in post-myocardial infarction mice, suggesting that MMP9 regulates both macrophage pro- and anti-inflammatory phenotypes (33). Thus, MMP9 might have a dual role, in regulating both various inflammatory and repair processes, depending on the surrounding microenvironment (34). Of note, an increased risk of myocardial infarction in PHPT patients still exists 1 year after parathyroidectomy, but thereafter declines to normal levels, indicating a prolonged repair process after normalization of PTH and calcium levels (8). Furthermore, MMP9 is crucial in skeletal repair and mice lacking MMP9 have delayed skeletal healing, both in the initial stage of fracture repair as well as in the hard callus phase (35). Bone-tissue requires at least 6 months before remodelling has reached a new balance after parathyroidectomy (13), and the observed increase in MMP9 in PHPT patients after surgery might be due to tissue repair processes post-operatively. MMPs are important for a healthy tissue remodelling, as reviewed by PageMcCaw et al. (36). 

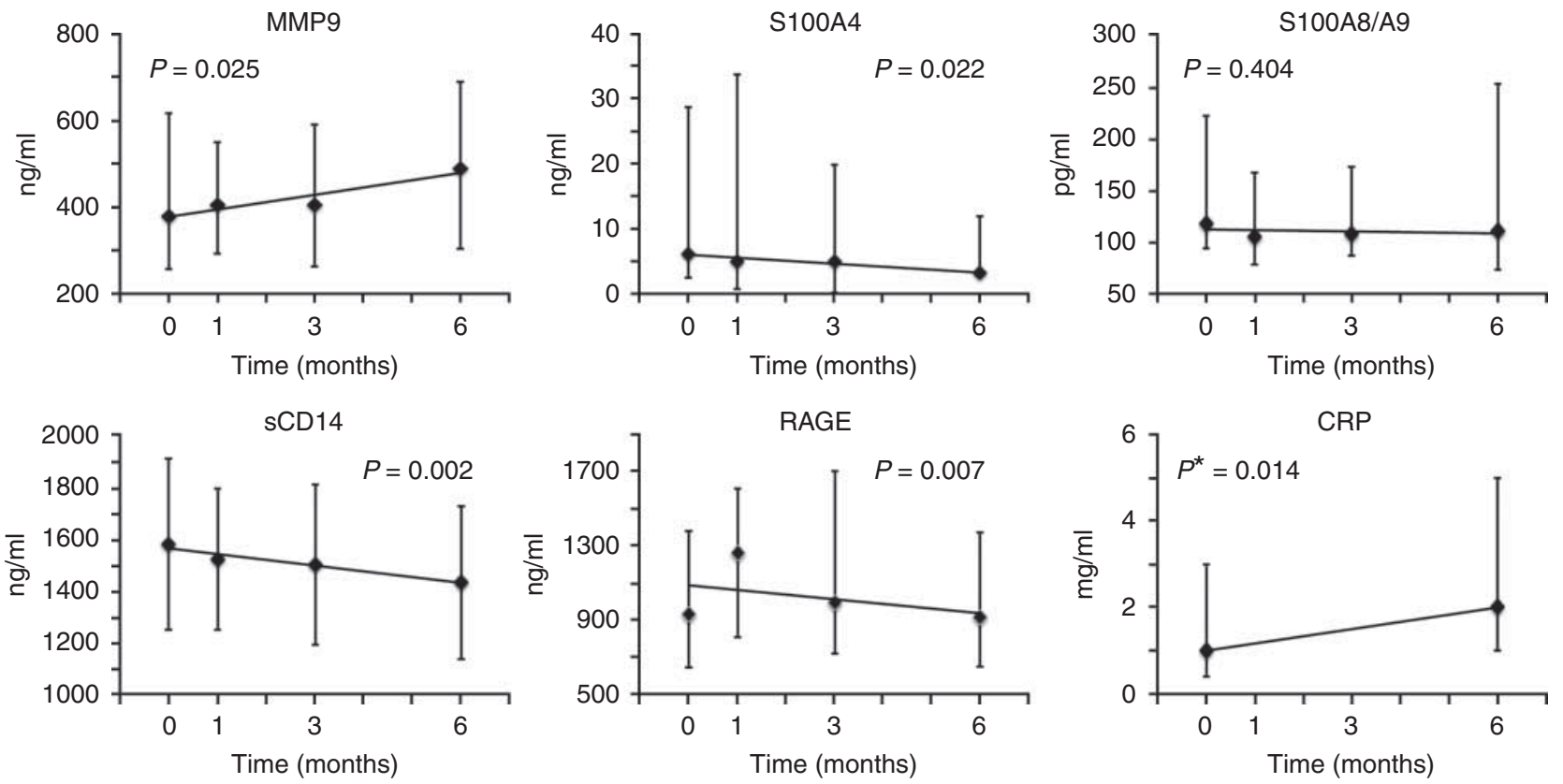

\section{Figure 2}

Inflammatory markers after parathyroidectomy. Samples were measured at baseline and after 1, 3 and 6 months in 42 patients treated surgically. $P$ values for trend over time are estimated with a random intercept mixed model. $P^{*}$ value is based on

Increased levels of CRP, together with interleukin-6 (IL6) 1 year after parathyroidectomy, have previously been described $(3,16,37)$. This corresponds with the increase in MMP9 observed in the present study. Additionally, serum levels of MMP9 and CRP were positively correlated. The mechanisms behind the increase of inflammatory markers after surgery are not fully understood. It seems that some inflammatory pathways recover after parathyroidectomy while other processes remain activated even as long as 2 years after surgery (15).

Expression of S100A4 is enhanced in several chronic inflammatory conditions, and concentrations are correlated with disease activity (20). S100A4 induces the production of pro-inflammatory proteins such as TNF- $\alpha$, IL1 $\beta$ and IL6 in mononuclear cells (38). Additionally, S100A4 is responsible for myeloid cell recruitment to sites of inflammation and an acceleration of the inflammatory processes (39). The reported increased levels in patients with PHPT confirm an inflammatory response with activation of RAGE and TLR-4. During 6 months follow-up, S100A4 was reduced, showing a partial recovery of the inflammation.

S100A8 and S100A9 were the two most upregulated genes in adipose tissue in our gene-expression study (18),
Wilcoxon ranked-signed test. CRP measurements at 1 and 3 months were not available. Data are given as median (25th to 75th percentile) for serum MMP9, plasma S100A4, plasma S100A8/A9, and serum RAGE, and mean (s.D.) for serum SCD14.

though serum levels of the heterodimer S100A8/A9 were not elevated. Measuring serum-levels of these two proteins is challenging because they heterodimerise quickly after release into the circulation, either with each other or other S100-proteins, such as S100A4 (40). The lack of increase in circulating S100A8/A9 might be explained by some of the S100A9 proteins being used to form the heterodimers with S100A4.

Secretion of sCD14 from the liver is induced by IL6 and $\mathrm{sCD} 14$ is regarded as an acute phase protein (41). Membrane bound CD14 (mCD14) is expressed on the surface of monocytes/macrophages and is activated by lipopolysaccharides (42). This receptor has been shown to regulate monocyte activation, leucocyte-endothelial cell interaction and cell apoptosis (43). sCD14 is derived by enzymatic cleavage of cell membrane-bound CD14, as well as through secretion from the liver, though the CD14 expression is regulated differently in hepatocytes and monocytes (44). sCD14 was positively correlated with cardio-metabolic risk factors and all cause mortality in older adults (21). The increased concentrations of sCD14 in PHPT patients compared to healthy controls in our study confirm the increased inflammation and risk of CVD in these patients. Additionally, the decrease in sCD14 after 
parathyroidectomy supports the partial reversal of the inflammatory processes. This is in accordance with the observed changes in S100A4 levels.

Vitamin D inadequacy is more frequent in PHPT patients than in the background population $(2,45)$ and low levels of $25(\mathrm{OH}) \mathrm{D}$ in these patients may be explained by increased activity of both the $1 \alpha$-hydroxylase and the 24-hydroxylase $(46,47)$. As expected, we found lower levels of $25(\mathrm{OH}) \mathrm{D}$ and higher levels of $1,25(\mathrm{OH})_{2} \mathrm{D}$ in patients with PHPT as compared to controls. Vitamin D has pleotropic effects including regulation of the immune system's cells (48). However, with the exception of a positive correlation between $25(\mathrm{OH}) \mathrm{D}$ and sCD14, we did not observe associations between the levels of $25(\mathrm{OH}) \mathrm{D}$ and $1,25(\mathrm{OH})_{2} \mathrm{D}$, and the inflammatory markers investigated in this study. The correlation between $25(\mathrm{OH}) \mathrm{D}$ and sCD14 was unexpected and should be followed up in later studies. Of note, the metabolically most active vitamin $\mathrm{D}$ metabolite $1,25(\mathrm{OH})_{2} \mathrm{D}$ was not correlated to sCD14.

RAGE and TLR4 are two important receptors in the inflammatory pathways. Several of the $S 100$ proteins, such as both S100A4 and S100A8/A9 bind to and initiate the inflammatory response through these receptors $(40,49)$. Increased expression of the immunoglobulin superfamily molecule RAGE was found in macrophages and smooth muscle cells in coronary artery plaque in diabetic subjects dying suddenly (50). Though, in the Dallas Heart Study an inverse association between sRAGE and coronary artery calcium was observed (51). A protective role of sRAGE for metabolic syndrome and atherosclerosis was also shown in both diabetic and nondiabetic subjects (22). Circulating levels of RAGE were not increased in patients with PHPT, corresponding to the similar mRNA-levels in adipose tissue when comparing PHPT patients with the control group (18). Interestingly, RAGE increased at 1 month after surgery, but was subsequently reduced to levels similar to concentrations at baseline during follow-up. Thus, increase of sRAGE after surgery might reflect a protective repair mechanism, which finally is associated with a decrease in cardiovascular risk possibly initiated by normalization of PTH and calcium after parathyroidectomy.

In the present study, the pathogenic mechanisms behind the increased inflammatory response in patients with PHPT have not been characterised, and further studies are warranted to investigate this issue. Our data are based in blood samples that have been collected under nonfasting conditions. Since food intake may influence the inflammatory responses (52), we cannot rule out the possibility that meals modulate these inflammatory biomarkers. Due to strict inclusion criteria and a limited number of available blood donors, we had an uneven gender distribution between the patient and control groups. Changes in inflammatory markers between patients and controls were adjusted for gender to correct for this. Another limitation was the follow-up rate in the longitudinal study ( 42 of the 57 patients); four patients were excluded due to consistently elevated serum levels of corrected Ca after surgery and 11 patients did not attend the follow-up visits.

In summary, we have reported an increase in novel inflammatory biomarkers in patients with PHPT. Measuring increased protein levels corresponding to the mRNA levels in adipose tissue of these biomarkers confirms the general inflammatory state in patients with PHPT. After parathyroidectomy, MMP9 increased, which possibly reflects tissue repair processes. S100A4 and sCD14 decreased after surgery indicating, at least a partial, recovery from the inflammatory response. Though, no conclusion on causal interference can be drawn based on this study as observed associations are presented. Further research is required to evaluate the use of these biomarkers as CVD risk factors in PHPT.

\section{Declaration of interest}

The authors declare that there is no conflict of interest that could be perceived as prejudicing the impartiality of the research reported.

\section{Funding}

Funding for this project was provided by Samarbeidsorganet Helse Vest RHF (http://www.helse-bergen.no/forskning/samarbeidsorganet) and by support from Familien Blix fond til fremme av medisinsk forskning, Oslo, Norway.

\section{Author contribution statement}

We confirm that all the named authors contributed substantially to the article and agree to take public responsibility for the validity of its content.

\section{Acknowledgements}

We are grateful to Dr Line Bjørge, Haukeland University Hospital, for expert advice during the writing process, and the staff at the Hormone Laboratory, Haukeland University Hospital, in particular Hege Skavøy Hoff, for technical assistance.

\section{References}

1 Fraser WD. Hyperparathyroidism. Lancet 2009374 145-158. (doi:10.1016/S0140-6736(09)60507-9)

2 Moosgaard B, Vestergaard P, Heickendorff L, Melsen F, Christiansen P \& Mosekilde L. Vitamin D status, seasonal variations, parathyroid 
adenoma weight and bone mineral density in primary hyperparathyroidism. Clinical Endocrinology 200563 506-513. (doi:10.1111/ j.1365-2265.2005.02371.x)

3 Almqvist EG, Bondeson AG, Bondeson L \& Svensson J. Increased markers of inflammation and endothelial dysfunction in patients with mild primary hyperparathyroidism. Scandinavian Journal of Clinical and Laboratory Investigation 201171 139-144. (doi:10.3109/00365513.2010. 543694)

4 Hagstrom E, Lundgren E, Rastad J \& Hellman P. Metabolic abnormalities in patients with normocalcemic hyperparathyroidism detected at a population-based screening. European Journal of Endocrinology 2006155 33-39. (doi:10.1530/eje.1.02173)

5 Ahlstrom T, Hagstrom E, Larsson A, Rudberg C, Lind L \& Hellman P. Correlation between plasma calcium, parathyroid hormone (PTH) and the metabolic syndrome (MetS) in a community-based cohort of men and women. Clinical Endocrinology 200971 673-678. (doi:10.1111/ j.1365-2265.2009.03558.x)

6 Luigi P, Chiara FM, Laura Z, Cristiano M, Giuseppina C, Luciano C, Giuseppe P, Sabrina C, Susanna S, Antonio C et al. Arterial hypertension, metabolic syndrome and subclinical cardiovascular organ damage in patients with asymptomatic primary hyperparathyroidism before and after parathyroidectomy: preliminary results. International Journal of Endocrinology 20122012 408295. (doi:10.1155/ 2012/408295)

7 Øgard CG, Engholm G, Almdal TP \& Vestergaard H. Increased mortality in patients hospitalized with primary hyperparathyroidism during the period 1977-1993 in Denmark. World Journal of Surgery 2004 28 108-111. (doi:10.1007/s00268-003-7046-0)

8 Vestergaard P, Mollerup CL, Frokjaer VG, Christiansen P, BlichertToft M \& Mosekilde L. Cardiovascular events before and after surgery for primary hyperparathyroidism. World Journal of Surgery 200327 216-222. (doi:10.1007/s00268-002-6589-9)

9 Andersson P, Rydberg E \& Willenheimer R. Primary hyperparathyroidism and heart disease - a review. European Heart Journal 200425 1776-1787. (doi:10.1016/j.ehj.2004.07.010)

10 Hagstrom E, Hellman P, Larsson TE, Ingelsson E, Berglund L, Sundstrom J, Melhus H, Held C, Lind L, Michaelsson K et al. Plasma parathyroid hormone and the risk of cardiovascular mortality in the community. Circulation 2009119 2765-2771. (doi:10.1161/CIRCULATIONAHA.108.808733)

$11 \mathrm{Yu}$ N, Leese GP \& Donnan PT. What predicts adverse outcomes in untreated primary hyperparathyroidism? The Parathyroid Epidemiology and Audit Research Study (PEARS). Clinical Endocrinology 201379 27-34. (doi:10.1111/cen.12206)

12 Rodgers SE, Lew JI \& Solorzano CC. Primary hyperparathyroidism. Current Opinion in Oncology 200820 52-58. (doi:10.1097/CCO. Ob013e3282f2838f)

13 Christiansen P, Steiniche T, Brixen K, Hessov I, Melsen F, Heickendorff L \& Mosekilde L. Primary hyperparathyroidism: effect of parathyroidectomy on regional bone mineral density in Danish patients: a three-year follow-up study. Bone 199925 589-595. (doi:10.1016/S8756-3282(99)00207-0)

14 Øgard CG, Engelmann MD, Kistorp C, Nielsen SL \& Vestergaard H. Increased plasma N-terminal pro-B-type natriuretic peptide and markers of inflammation related to atherosclerosis in patients with primary hyperparathyroidism. Clinical Endocrinology 200563 493-498. (doi:10.1111/j.1365-2265.2005.02363.x)

15 Bollerslev J, Rosen T, Mollerup CL, Nordenstrom J, Baranowski M, Franco C, Pernow Y, Isaksen GA, Godang K, Ueland T et al. Effect of surgery on cardiovascular risk factors in mild primary hyperparathyroidism. Journal of Clinical Endocrinology and Metabolism 200994 2255-2261. (doi:10.1210/jc.2008-2742)

16 Christensen MH, Pedersen EK, Nordbo Y, Varhaug JE, Midttun O, Ueland PM, Nygard OK, Mellgren G \& Lien EA. Vitamin B6 status and interferon- $\gamma$-mediated immune activation in primary hyperparathyroidism. Journal of Internal Medicine 2012272 583-591. (doi:10.1111/j.1365-2796.2012.02570.x)

17 Hansson GK, Libby P, Schonbeck U \& Yan ZQ. Innate and adaptive immunity in the pathogenesis of atherosclerosis. Circulation Research 200291 281-291. (doi:10.1161/01.RES.0000029784.15893.10)

18 Christensen MH, Dankel SN, Nordbo Y, Varhaug JE, Almas B, Lien EA \& Mellgren G. Primary hyperparathyroidism influences the expression of inflammatory and metabolic genes in adipose tissue. PLoS ONE 20116 e20481. (doi:10.1371/journal.pone.0020481)

19 Tayebjee MH, Nadar S, Blann AD, Gareth Beevers D, MacFadyen RJ \& Lip GY. Matrix metalloproteinase-9 and tissue inhibitor of metalloproteinase-1 in hypertension and their relationship to cardiovascular risk and treatment: a substudy of the Anglo-Scandinavian Cardiac Outcomes Trial (ASCOT). American Journal of Hypertension 2004 17 764-769. (doi:10.1016/j.amjhyper.2004.05.019)

20 Oslejskova L, Grigorian M, Hulejova H, Vencovsky J, Pavelka K, Klingelhofer J, Gay S, Neidhart M, Brabcova H, Suchy D et al. Metastasis-inducing S100A4 protein is associated with the disease activity of rheumatoid arthritis. Rheumatology 200948 1590-1594. (doi:10.1093/rheumatology/kep316)

21 Reiner AP, Lange EM, Jenny NS, Chaves PH, Ellis J, Li J, Walston J, Lange LA, Cushman M \& Tracy RP. Soluble CD14: genomewide association analysis and relationship to cardiovascular risk and mortality in older adults. Arteriosclerosis, Thrombosis, and Vascular Biology 201333 158-164. (doi:10.1161/ATVBAHA.112.300421)

22 Koyama H, Shoji T, Yokoyama H, Motoyama K, Mori K, Fukumoto S, Emoto M, Shoji T, Tamei H, Matsuki H et al. Plasma level of endogenous secretory RAGE is associated with components of the metabolic syndrome and atherosclerosis. Arteriosclerosis, Thrombosis, and Vascular Biology 200525 2587-2593. (doi:10.1161/01.ATV. 0000190660.32863.cd)

23 Holm PI, Ueland PM, Kvalheim G \& Lien EA. Determination of choline, betaine, and dimethylglycine in plasma by a high-throughput method based on normal-phase chromatography-tandem mass spectrometry. Clinical Chemistry 200349 286-294. (doi:10.1373/ 49.2.286)

24 Grimnes G, Almaas B, Eggen AE, Emaus N, Figenschau Y, Hopstock LA, Hutchinson MS, Methlie P, Mihailova A, Sneve M et al. Effect of smoking on the serum levels of 25-hydroxyvitamin D depends on the assay employed. European Journal of Endocrinology 2010163 339-348. (doi:10.1530/EJE-10-0150)

25 Payne RB, Little AJ, Williams RB \& Milner JR. Interpretation of serum calcium in patients with abnormal serum proteins. British Medical Journal 19734 643-646. (doi:10.1136/bmj.4.5893.643)

26 Levey AS, Coresh J, Greene T, Marsh J, Stevens LA, Kusek JW \& Van Lente F. Expressing the Modification of Diet in Renal Disease Study equation for estimating glomerular filtration rate with standardized serum creatinine values. Clinical Chemistry 200753 766-772. (doi:10.1373/clinchem.2006.077180)

27 Ma Y, Yabluchanskiy A, Hall ME \& Lindsey ML. Using plasma matrix metalloproteinase-9 and monocyte chemoattractant protein-1 to predict future cardiovascular events in subjects with carotid atherosclerosis. Atherosclerosis 2014232 231-233. (doi:10.1016/ j.atherosclerosis.2013.09.013)

28 Siwik DA, Pagano PJ \& Colucci WS. Oxidative stress regulates collagen synthesis and matrix metalloproteinase activity in cardiac fibroblasts. American Journal of Physiology. Cell Physiology 2001280 C53-C60.

29 Tschesche H, Zolzer V, Triebel S \& Bartsch S. The human neutrophil lipocalin supports the allosteric activation of matrix metalloproteinases. European Journal of Biochemistry/FEBS 2001268 1918-1928. (doi:10.1046/j.1432-1327.2001.02066.x)

30 Jackson MT, Moradi B, Smith MM, Jackson CJ \& Little CB. Activation of matrix metalloproteinases 2,9 , and 13 by activated protein $\mathrm{C}$ in human osteoarthritic cartilage chondrocytes. Arthritis \& Rheumatology 201466 1525-1536. (doi:10.1002/art.38401) 
31 Tan C, Liu Y, Li W, Deng F, Liu X, Wang X, Gui Y, Qin L, Hu C \& Chen L. Associations of matrix metalloproteinase- 9 and monocyte chemoattractant protein-1 concentrations with carotid atherosclerosis, based on measurements of plaque and intima-media thickness. Atherosclerosis 2014232 199-203. (doi:10.1016/j.atherosclerosis. 2013.11.040)

32 Blankenberg S, Rupprecht HJ, Poirier O, Bickel C, Smieja M, Hafner G, Meyer J, Cambien F \& Tiret L. Plasma concentrations and genetic variation of matrix metalloproteinase 9 and prognosis of patients with cardiovascular disease. Circulation 2003107 1579-1585. (doi:10.1161/01.CIR.0000058700.41738.12)

33 Zamilpa R, Ibarra J, de Castro Bras LE, Ramirez TA, Nguyen N, Halade GV, Zhang J, Dai Q, Dayah T, Chiao YA et al. Transgenic overexpression of matrix metalloproteinase-9 in macrophages attenuates the inflammatory response and improves left ventricular function post-myocardial infarction. Journal of Molecular and Cellular Cardiology 201253 599-608. (doi:10.1016/j.yjmcc.2012.07.017)

34 Parks WC, Wilson CL \& Lopez-Boado YS. Matrix metalloproteinases as modulators of inflammation and innate immunity. Nature Reviews. Immunology 20044 617-629. (doi:10.1038/nri1418)

35 Colnot C, Thompson Z, Miclau T, Werb Z \& Helms JA. Altered fracture repair in the absence of MMP9. Development $20031304123-4133$. (doi:10.1242/dev.00559)

36 Page-McCaw A, Ewald AJ \& Werb Z. Matrix metalloproteinases and the regulation of tissue remodelling. Nature Reviews. Molecular Cell Biology 20078 221-233. (doi:10.1038/nrm2125)

37 Farahnak P, Larfars G, Sten-Linder M \& Nilsson IL. Mild primary hyperparathyroidism: vitamin D deficiency and cardiovascular risk markers. Journal of Clinical Endocrinology and Metabolism 201196 2112-2118. (doi:10.1210/jc.2011-0238)

38 Cerezo LA, Remakova M, Tomcik M, Gay S, Neidhart M, Lukanidin E, Pavelka K, Grigorian M, Vencovsky J \& Senolt L. The metastasisassociated protein $\mathrm{S100A4}$ promotes the inflammatory response of mononuclear cells via the TLR4 signalling pathway in rheumatoid arthritis. Rheumatology 201453 1520-1526. (doi:10.1093/ rheumatology/keu03)

39 Li ZH, Dulyaninova NG, House RP, Almo SC \& Bresnick AR. S100A4 regulates macrophage chemotaxis. Molecular Biology of the Cell 201021 2598-2610. (doi:10.1091/mbc.E09-07-0609)

40 Bjork P, Kallberg E, Wellmar U, Riva M, Olsson A, He Z, Torngren M, Liberg D, Ivars $\mathrm{F} \&$ Leanderson T. Common interactions between S100A4 and S100A9 defined by a novel chemical probe. PLoS ONE 2013 8 e63012. (doi:10.1371/journal.pone.0063012)

41 Bas S, Gauthier BR, Spenato U, Stingelin S \& Gabay C. CD14 is an acute-phase protein. Journal of Immunology 2004172 4470-4479. (doi:10.4049/jimmunol.172.7.4470)
42 Durieux JJ, Vita N, Popescu O, Guette F, Calzada-Wack J, Munker R, Schmidt RE, Lupker J, Ferrara P, Ziegler-Heitbrock HW et al. The two soluble forms of the lipopolysaccharide receptor, CD14: characterization and release by normal human monocytes. European Journal of Immunology 199424 2006-2012. (doi:10.1002/eji.1830240911)

43 Arroyo-Espliguero R, Avanzas P, Jeffery S \& Kaski JC. CD14 and toll-like receptor 4: a link between infection and acute coronary events? Heart 200490 983-988. (doi:10.1136/hrt.2002.001297)

44 Pan Z, Zhou L, Hetherington CJ \& Zhang DE. Hepatocytes contribute to soluble CD14 production, and CD14 expression is differentially regulated in hepatocytes and monocytes. Journal of Biological Chemistry 2000275 36430-36435. (doi:10.1074/jbc.M003192200)

45 Boudou P, Ibrahim F, Cormier C, Sarfati E \& Souberbielle JC. A very high incidence of low 25 hydroxy-vitamin D serum concentration in a French population of patients with primary hyperparathyroidism. Journal of Endocrinological Investigation 200629 511-515. (doi:10.1007/ BF03344140)

46 Lips P. Vitamin D deficiency and secondary hyperparathyroidism in the elderly: consequences for bone loss and fractures and therapeutic implications. Endocrine Reviews 200122 477-501. (doi:10.1210/edrv.22.4.0437)

47 Tashiro K, Abe T, Oue N, Yasui W \& Ryoji M. Characterization of vitamin D-mediated induction of the CYP 24 transcription. Molecular and Cellular Endocrinology 2004226 27-32. (doi:10.1016/ j.mce.2004.07.012)

48 DeLuca HF. Overview of general physiologic features and functions of vitamin D. American Journal of Clinical Nutrition 200480 1689S-1696S.

49 Hofmann MA, Drury S, Fu C, Qu W, Taguchi A, Lu Y, Avila C, Kambham N, Bierhaus A, Nawroth P et al. RAGE mediates a novel proinflammatory axis: a central cell surface receptor for S100/calgranulin polypeptides. Cell 199997 889-901. (doi:10.1016/ S0092-8674(00)80801-6)

50 Burke AP, Kolodgie FD, Zieske A, Fowler DR, Weber DK, Varghese PJ, Farb A \& Virmani R. Morphologic findings of coronary atherosclerotic plaques in diabetics: a postmortem study. Arteriosclerosis, Thrombosis, and Vascular Biology 200424 1266-1271. (doi:10.1161/01.ATV. 0000131783.74034.97)

51 Lindsey JB, de Lemos JA, Cipollone F, Ayers CR, Rohatgi A, Morrow DA, Khera A \& McGuire DK. Association between circulating soluble receptor for advanced glycation end products and atherosclerosis: observations from the Dallas Heart Study. Diabetes Care 200932 1218-1220. (doi:10.2337/dc09-0053)

52 Alvarez JA, Higgins PB, Oster RA, Fernandez JR, Darnell BE \& Gower BA. Fasting and postprandial markers of inflammation in lean and overweight children. American Journal of Clinical Nutrition 200989 1138-1144. (doi:10.3945/ajcn.2008.26926)

Received 26 November 2014

Revised version received 5 March 2015

Accepted 7 April 2015 